\title{
Assessment of Groundwater Suitability for Drinking and Irrigation Purpose in the Dimbhe Command Area of River Ghod, Maharashtra, India
}

\author{
Geeta Pillai, I. A. Khan \\ Department of Geology \& Petroleum Technology, N. Wadia College, Pune, India \\ Email: geetapillai54@gmail.com
}

How to cite this paper: Pillai, G. and Khan, I.A. (2016) Assessment of Groundwater Suitability for Drinking and Irrigation Purpose in the Dimbhe Command Area of River Ghod, Maharashtra, India. Journal ot Geoscience and Environment Protection, 4, 142-157.

http://dx.doi.org/10.4236/gep.2016.412011

Received: October 15, 2016

Accepted: December 26, 2016

Published: December 29, 2016

Copyright $\odot 2016$ by authors and Scientific Research Publishing Inc. This work is licensed under the Creative Commons Attribution International License (CC BY 4.0).

http://creativecommons.org/licenses/by/4.0/

\begin{abstract}
The management of the subsurface and surface water resources is important for various purposes. Since the quantity and quality of water available for irrigation in India is variable from place to place, groundwater quality in the Dimbhe command area was evaluated for its suitability for domestic and irrigation purposes by collecting 37 dug well samples during the post monsoon period of 2014. The suitability assessment was made by estimating $\mathrm{pH}$, electrical conductivity, total dissolved solids, and alkalinity besides major cations $\left(\mathrm{Na}^{+}, \mathrm{K}^{+}, \mathrm{Ca}^{2+}\right.$, and $\left.\mathrm{Mg}^{2+}\right)$ and anions $\left(\mathrm{HCO}_{3}^{-}, \mathrm{Cl}^{-}\right.$, $\mathrm{SO}_{4}^{2-}$, and $\mathrm{NO}_{3}^{-}$). Out of 37 groundwater samples, 5.41\% represents good water, $62.16 \%$ indicate poor water, $29.73 \%$ indicate very poor water and $2.7 \%$ indicate water unsuitable for domestic purposes. Based on these analyses, irrigation quality parameters like, sodium absorption ratio, permeability index, Kelley's ratio, soluble sodium percentage, residual sodium carbonate, $\% \mathrm{Mg}, \% \mathrm{Na}$, and $\mathrm{Mg}$ hazard ratio were calculated. Assessment of groundwater samples indicated that majority of them in both the seasons are suitable for irrigation purposes.
\end{abstract}

\section{Keywords}

Irrigation Water, Groundwater Suitability, Dimbhe Command Area

\section{Introduction}

Groundwater is a limited water resource, but requirement of water is increasing day by day. Where surface water is not available due to high slope area or feasible for consumption, the groundwater potential is suitable in quantity or quality. The contamination of groundwater cannot be polluted easily ascompared with surface water because it is protected naturally, so it is more reliable [1] [2]. Irrigation is a dominant sector in the 
economic development of India, as it is the source of more than $60 \%$ of irrigated agriculture and $85 \%$ of drinking water supplies are dependent on groundwater and the dependence on groundwater has increased tremendously in recent years in many parts of India, especially in the arid and semi-arid regions, due to the uncertaintyof monsoon and the scarcity of surface water [1] [2] [3]. Even though the quantity and quality of water available for irrigation is different in several parts of the world [1]-[6] and many groundwater exploitation schemes in developing countries like India are designed without due attention to quality issues [7] [8] [9] [10]. A number of studies on groundwater quality with respect to irrigation purposes have been carried out in different parts of India [1] [2] [3] [7] [8] [9] [10]. So far, the geochemistry and the suitability of the groundwater for drinking and irrigation purposes in the Dimbhe command area has not been studied in great detail. Since groundwater is intensively used for drinking and irrigation purposes, an effort is made in this paper to determine the groundwater suitability for same.

\section{Study Area}

The River Ghod of Dimbhe command area is one of the major tributaries of River Bhima in the northern Maharashtra that subsequently joins the River Krishna. It flows in an east-southeast direction for approximately $200 \mathrm{~km}$ before its confluence with the River Bhima. The Dimbhe dam is situated on the Ghod river basin (Figure 1). The River Ghod has its origin in the eastern slopes of the Western Ghats at approx. 1190 meters (3580 feet) above sea level. The Dimbhe dam lies in the Ambegaon Taluka of Pune district in the state of Maharashtra.

The study area is covered in the survey of India toposheets $47 \mathrm{E} / 12$ and $47 \mathrm{E} / 16$, with a command area under consideration of $281 \mathrm{~km}^{2}$ part of Ambegaon Taluka. Dimbhe Left Bank Canal (DLBC) takes off from Dimbhe dam. It is fully lined and creates the irrigable area of 2631 ha with $107 \%$ intensity of irrigation, the potential is 2815 ha. Dimbhe Right Bank Canal (DRBC) takes off from DLBC at chainage km 2.75 and runs for $116 \mathrm{~km}$ and lined up to $102 \mathrm{~km}$., creates an irrigable area of 14549 ha with $107 \%$ intensity of irrigation; the potential of this canal is $15,568 \mathrm{ha}$. Canal works from km. 1 to 99 are almost completed except lining from Km. No. 5, Km 100 to 116 are in progress. Recently, the water released into the canal isup to $80 \mathrm{~km}$.

\section{Material and Methodology}

\subsection{Data Collection}

A total of 37 groundwater samples (Figure 1) were collected in the command area of the Ghod River basin during the post-monsoon season in November 2014. The water samples were collected in one liter capacity pre-washed poly-ethylene containers. For trace element analyses, water samples were collected separately in $100 \mathrm{ml}$ pre-washed poly-ethylene containers and acidified with $0.5 \mathrm{ml}$ conc. $\mathrm{HNO}_{3}$. Simultaneously, static water levels, depth of wells, $\mathrm{pH}$ and Electrical Conductivity (EC) and Total dissolve solid (TDS) were recorded at the time of sampling. GPS readings were taken for loca- 


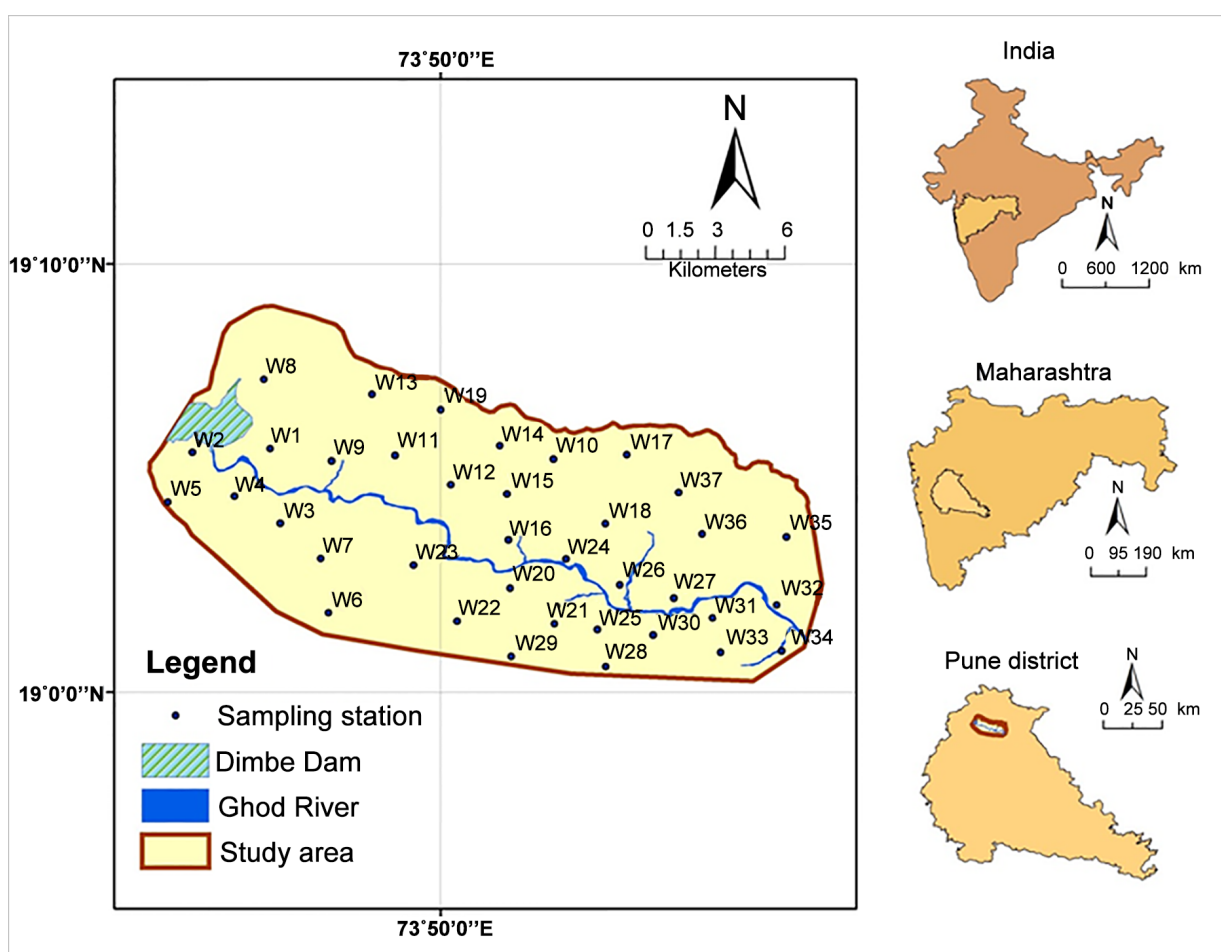

Figure 1. Location map of study area showing sampling station.

tion and altitudes. Observations were also carried out regarding local geology, rock type, aquifer type and degree and depth of weathering/fracturing/jointing pattern from dug wells sections and outcrops exposed in the field.

\subsection{Sampling and Data Analyses}

The major anionic (Bicarbonates $\left(\mathrm{HCO}_{3}^{-}\right)$, Chlorides $(\mathrm{Cl})$, Nitrates $\left(\mathrm{NO}_{3}^{-}\right)$Sulfates $\left(\mathrm{SO}_{4}^{2-}\right)$ and Boron (B)), cationic (Sodium $\left(\mathrm{Na}^{+}\right)$, Potassium $\left(\mathrm{K}^{+}\right)$, Calcium $\left(\mathrm{Ca}^{2+}\right)$ and Magnesium $\left(\mathrm{Mg}^{2+}\right)$ ) and other parameter like Total hardness $\left(\right.$ as $\left.\mathrm{CaCO}_{3}\right)$ concentrations were determined in the laboratory using the standard analytical procedures (Table 1) as recommended by the American Public Health Association (2005) [11]. The chargebalance error of the water samples is $>5 \%$, which is within the limits of acceptability.

The correlation analysis to establish the relationships between physicochemical characteristics of water samples was done. The Water Quality Index (WQI) was also derived from analyzed parameter, for determining groundwater quality and its suitability fordrinking purposes.

Based on the physico-chemical analyses, irrigation quality parameters like sodium absorption ratio (SAR), \%Na, residual sodium carbonate (RSC), soluble sodium percentage (SSP), permeability index (PI), Kelley's Index (KI) and magnesium hazard $(\mathrm{MH})$ were calculated. The suitability of the water from the groundwater sources for irrigation purposes was evaluated by comparing the values of different water quality parameters with those of the Bureau of Indian standards (BIS 1998) [12] for drinking water. 
Table 1. Physico-chemical and irrigation quality parameters with BIS standards.

\begin{tabular}{|c|c|c|c|c|c|}
\hline Sr No & $\begin{array}{l}\text { Category of } \\
\text { parameter }\end{array}$ & Characteristics & Analytical method & Unit & $\begin{array}{c}\text { BIS Max. Permissible } \\
\text { limit (1998) }\end{array}$ \\
\hline 1 & General & $\mathrm{pH}$ & Electrode & & $6.5-8.5$ \\
\hline 2 & & $\mathrm{EC}$ & Conductivity meter & $\mu \mathrm{S} / \mathrm{cm}$ & 3000 \\
\hline 3 & & TDS & TDS meter & $\mathrm{mg} / \mathrm{L}$ & 2000 \\
\hline 4 & & $\begin{array}{l}\text { Total hardness } \\
\quad\left(\text { as } \mathrm{CaCO}_{3}\right)\end{array}$ & EDTA titrimetric & $\mathrm{mg} / \mathrm{L}$ & 600 \\
\hline 5 & Major cations & Sodium $\left(\mathrm{Na}^{+}\right)$ & Flame photometric & $\mathrm{mg} / \mathrm{L}$ & 200 \\
\hline 6 & & Potassium $\left(\mathrm{K}^{+}\right)$ & Flame photometric & $\mathrm{mg} / \mathrm{L}$ & 10 \\
\hline 7 & & Calcium $\left(\mathrm{Ca}^{2+}\right)$ & EDTA titrimetric & $\mathrm{mg} / \mathrm{L}$ & 200 \\
\hline 8 & & Magnesium $\left(\mathrm{Mg}^{2+)}\right.$ & EDTA titrimetric & $\mathrm{mg} / \mathrm{L}$ & 100 \\
\hline 9 & Major anions & Bicarbonates $\left(\mathrm{HCO}_{3}^{-}\right)$ & Titrimetric & $\mathrm{mg} / \mathrm{L}$ & NA \\
\hline 10 & & Chlorides $\left(\mathrm{Cl}^{-}\right)$ & Titrimetric & $\mathrm{mg} / \mathrm{L}$ & 1000 \\
\hline 11 & & Nitrates $\left(\mathrm{NO}_{3}^{-}\right)$ & Titrimetric & $\mathrm{mg} / \mathrm{L}$ & 45 \\
\hline 12 & & Sulfates $\left(\mathrm{SO}_{4}^{2-}\right)$ & Barium chloride & $\mathrm{mg} / \mathrm{L}$ & 400 \\
\hline 13 & & Boron (B) & Curcumin method & $\mathrm{mg} / \mathrm{L}$ & - \\
\hline 14 & $\begin{array}{c}\text { Irrigation water } \\
\text { quality }\end{array}$ & Salinity & & $\%$ & NA \\
\hline 15 & & SAR & & - & $<10$ or $10-18$ \\
\hline 16 & & RSC & & $\mathrm{meq} / \mathrm{L}$ & $<1.25$ \\
\hline 17 & & $\% \mathrm{Na}$ & & $\%$ & $<20$ or $20-40$ \\
\hline 18 & & PI & & $\%$ & Class 1 or 2 \\
\hline 19 & & $\mathrm{KI}$ & & - & $<1.0$ \\
\hline 20 & & MH & & $\%$ & Below $50 \%$ \\
\hline 21 & & SSP & & - & NA \\
\hline
\end{tabular}

\section{Results}

\subsection{Groundwater Quality Analysis for Drinking}

\subsubsection{General Parameters Analysis}

The values of $\mathrm{pH}$ in the groundwater samples collected from the study area varied from 7.06 to 8.80 , indicating a slightly acidic to slightly basic nature. All the samples showed a $\mathrm{pH}$ value within the permissible limit of 6.5 - 8.5 [12], except sample number W16 and W17. The analytical results for the groundwater samples of the study area are presented in Table 2. The electrical conductivity (EC) of groundwater in the study area varies widely and ranges between 860 and $6770 \mu \mathrm{S} / \mathrm{cm}$ and 19 samples showed the conductivity value higher than permissible limit of $3000 \mu \mathrm{S} / \mathrm{cm}[12]$.

The TDS values varied between 70 and $4401 \mathrm{mg} / \mathrm{L}$ and 9 samples showed TDS value above the permissible limit of $2000 \mathrm{mg} / \mathrm{L}$ [2]. Water hardness is caused primarily by the presence of cations such as calcium and magnesium and anions such as carbonate, 
Table 2. Physicochemical analysis of water from post-monsoon 2014.

\begin{tabular}{|c|c|c|c|c|c|c|c|c|c|c|c|c|c|}
\hline Name & $\mathrm{pH}$ & $\mathrm{EC}$ & TDS & $\mathrm{TH}$ & $\mathrm{Na}$ & K & $\mathrm{Ca}$ & $\mathrm{Mg}$ & $\mathrm{HCO}_{3}$ & CI & $\mathrm{SO}_{4}$ & $\mathrm{NO}_{3}$ & B \\
\hline W1 & 7.5 & & 210.0 & & 540 & 1.4 & 162.6 & & & 15.6 & 129.0 & 1.4 & \\
\hline W2 & 8.3 & 3021 & 70.0 & 65.02 & 39.0 & 0.9 & 65.0 & 45.0 & 424.0 & 11.7 & 63.0 & 1.1 & ND \\
\hline W3 & 7.9 & 2738 & 230.0 & 160.64 & 28.0 & 1.1 & 160.6 & 47.0 & 360.0 & 24.0 & 98.0 & 0.1 & 1.01 \\
\hline W4 & 7.6 & 4210 & 400.0 & 288.24 & 47.0 & 2.5 & 282.8 & 72.0 & 273.0 & 36.0 & 37.0 & ND & 0.96 \\
\hline W5 & 7.1 & 3217 & 370.0 & 284.48 & 35.0 & 1.4 & 284.5 & 68.0 & 310.0 & 30.5 & 68.0 & 9.4 & 0.34 \\
\hline W6 & 7.5 & 2894 & 350.0 & 539 & 48.0 & 2.8 & 252.0 & 51.0 & 181.0 & 15.6 & 109.0 & 109.0 & ND \\
\hline W7 & 7.5 & 3210 & 320.0 & 243.84 & 39.0 & 2.5 & 243.8 & 65.0 & 196.0 & 23.4 & 136.0 & 19.2 & 0.21 \\
\hline W8 & 7.6 & 3742 & 320.0 & 243.84 & 42.0 & 1.6 & 243.8 & 29.0 & 162.0 & 19.5 & 112.0 & 27.0 & 0.78 \\
\hline W9 & 7.7 & 1270 & 320.0 & 247.9 & 68.0 & 1.4 & 247.9 & 43.0 & 602.0 & 19.5 & 68.0 & 2.1 & 0.43 \\
\hline W10 & 7.5 & 3210 & 510.0 & 290.08 & 64.0 & 1.5 & 390.1 & 67.0 & 448.0 & 28.7 & 73.0 & 16.7 & 0.34 \\
\hline W11 & 7.7 & 3249 & 510.0 & 364.56 & 110.0 & 1.3 & 364.6 & 41.0 & 431.0 & 23.0 & 83.0 & 19.0 & 1.21 \\
\hline W12 & 7.6 & 2246 & 640.0 & 380.24 & 86.0 & 1.4 & 380.2 & 52.0 & 398.0 & 40.2 & 72.0 & 19.1 & 1.01 \\
\hline W13 & 7.5 & 3641 & 370.0 & 231.28 & 79.0 & 1.7 & 321.4 & 84.0 & 268.0 & 21.0 & 68.0 & 7.5 & 1.09 \\
\hline W14 & 8.3 & 1790 & 1163.0 & 462 & 45.0 & 0.7 & 85.0 & 61.0 & 267.0 & 65.0 & 84.0 & 40.0 & 1.02 \\
\hline W15 & 8.0 & 1920 & 1248.0 & 479 & 35.0 & 0.6 & 80.0 & 68.0 & 235.0 & 90.0 & 34.0 & 52.0 & 1.85 \\
\hline W16 & 8.7 & 860.0 & 559.0 & 289 & 42.0 & 0.7 & 48.0 & 41.0 & 224.0 & 92.0 & 32.0 & 24.0 & 0.5 \\
\hline W17 & 8.8 & 910 & 591.0 & 369 & 53.0 & 0.5 & 82.0 & 40.0 & 312.0 & 61.0 & 82.0 & 32.0 & 0.64 \\
\hline W18 & 7.6 & 4670 & 3036.0 & 500 & 260.0 & 2.7 & 39.0 & 49.0 & 492.0 & 107.0 & 149.0 & 40.0 & 0.95 \\
\hline W19 & 8.3 & 5290 & 3439.0 & 154 & 210.0 & 1.3 & 89.0 & 27.0 & 550.0 & 110.0 & 164.0 & 30.0 & 0.05 \\
\hline W20 & 8.3 & 6770 & 4401.0 & 238 & 332.0 & 1.4 & 38.0 & 35.0 & 755.0 & 216.0 & 159.0 & 68.0 & 3.33 \\
\hline W21 & 8.4 & 5160 & 3354.0 & 150 & 280.0 & 1.5 & 21.0 & 24.0 & 583.0 & 146.0 & 161.0 & 52.0 & 2.74 \\
\hline W22 & 7.7 & 1850 & 1202.0 & 701 & 54.0 & 2.7 & 56.0 & 70.0 & 342.0 & 96.0 & 59.0 & 24.0 & 5.05 \\
\hline W23 & 7.6 & 3045 & 1979.0 & 568 & 110.0 & 2.8 & 76.0 & 92.0 & 241.0 & 251.0 & 82.0 & 48.0 & 0.05 \\
\hline W24 & 7.7 & 2890.0 & 1878.0 & 140 & 240.0 & 2.9 & 20.0 & 22.0 & 624.0 & 73.0 & 45.0 & 70.0 & 8.01 \\
\hline W25 & 8.0 & 4265 & 2772.0 & 794 & 110.0 & 3.0 & 60.0 & 60.0 & 440.0 & 172.0 & 32.0 & 65.0 & 5.09 \\
\hline W26 & 8.1 & 4280 & 2782.0 & 415 & 80.0 & 2.5 & 48.0 & 60.0 & 32.0 & 110.0 & 82.0 & 32.0 & 1.64 \\
\hline W27 & 7.6 & 3236 & 2103.0 & 396 & 142.0 & 0.9 & 48.0 & 78.0 & 280.0 & 250.0 & 102.0 & 46.0 & 4.59 \\
\hline W28 & 8.2 & 2870 & 1866.0 & 432 & 78.0 & 1.6 & 35.0 & 44.0 & 232.0 & 85.0 & 118.0 & 52.0 & 3.7 \\
\hline W29 & 7.8 & 3720 & 2418.0 & 794 & 700 & 0.6 & 104.0 & 130.0 & 328.0 & 350.0 & 50.0 & 74.0 & 4.5 \\
\hline W30 & 7.2 & 1040 & 624.0 & 269 & 124.0 & 3.9 & 92.0 & 48.0 & 445.0 & 214.0 & 75.0 & 62.0 & 4 \\
\hline W31 & 8.4 & 920 & 1234.0 & 721 & 205.0 & 0.9 & 43.0 & 46.0 & 484.0 & 103.0 & 86.0 & 32.0 & 2.8 \\
\hline W32 & 7.8 & 1370 & 3650.0 & 432 & 118.0 & 1.4 & 64.0 & 66.0 & 369.0 & 144.0 & 170.0 & 28.0 & 2.02 \\
\hline W33 & 7.4 & 2928 & 491.0 & 375.36 & 88.0 & 1.3 & 383.4 & 43.0 & 299.0 & 68.0 & 168.0 & 38.7 & 1.71 \\
\hline W34 & 7.6 & 5163 & 385.0 & 298.08 & 78.0 & 1.5 & 506.9 & 69.0 & 418.0 & 39.9 & 112.0 & 38.4 & 0.96 \\
\hline W35 & 7.8 & 1613 & 472.0 & 364.32 & 373.0 & 1.7 & 298.2 & 72.0 & 121.0 & 60.0 & 98.0 & 38.6 & 0.58 \\
\hline W36 & 7.8 & 1890 & 236.0 & 187.68 & 63.0 & 2.3 & 196.0 & 54.0 & 164.0 & 24.0 & 45.0 & 15.5 & 0.36 \\
\hline W37 & 7.4 & 4315 & 667.0 & 305.44 & 59.0 & 1.4 & 289.7 & 92.0 & 98.0 & 56.0 & 68.0 & 38.6 & 1.01 \\
\hline Min & 7.1 & 860 & 70.0 & 65.02 & 28.0 & 0.5 & 20.0 & 22.0 & 32.0 & 11.7 & 32.0 & 0.14 & 0.05 \\
\hline $\operatorname{Max}$ & 8.8 & 6770 & 4401.0 & 794.00 & 373.0 & 3.9 & 506.9 & 130.0 & 755.0 & 350.0 & 170.0 & 109.0 & 8.01 \\
\hline Avg & 7.8 & 3007.1 & 1274.8 & 360.42 & 108.3 & 1.68 & 167.6 & 56.3 & 348.9 & 88.96 & 91.16 & 35.34 & 1.90 \\
\hline Stddev & 0.4 & 1410.6 & 1194.9 & 182.23 & 88.25 & 0.8 & 134.1 & 22.04 & 161.2 & 80.53 & 40.93 & 23.94 & 1.87 \\
\hline
\end{tabular}

All values are in $\mathrm{mg} / \mathrm{L}$ except, $\mathrm{pH}$ and E.C. $(\mu \mathrm{S} / \mathrm{cm}), \mathrm{ND}$ : not detected. 
bicarbonate, chloride, and sulfate in water. The total hardness $\left(\right.$ as $\left.\mathrm{CaCO}_{3}\right)$ values range between 65.02 and $794 \mathrm{mg} / \mathrm{L}$ in the post-monsoon samples in the study area; only 4 (i.e. W22, W25, W29 and W31) samples were having hardness values above the permissible limit of $600 \mathrm{mg} / \mathrm{L}$ [12].

The concentration of sodium and potassium ranged from 28 to 373 and 0.5 to 3.9 $\mathrm{mg} / \mathrm{L}$, respectively. Among the 37 samples, $18.92 \%$ was having high sodium content above the permissible limit of $200 \mathrm{mg} / \mathrm{L}$ [12], while all the samples showed a potassium concentration within the permissible limit of $10 \mathrm{mg} / \mathrm{L}$. The concentration of calcium and magnesium was in the range of 20 to 506.94 and 22 to $130 \mathrm{mg} / \mathrm{L}$, respectively. Among 37 samples, only 7 and 1 samples was having higher calcium and magnesium content in comparison to their BIS permissible limit of 200 and $100 \mathrm{mg} / \mathrm{L}$, respectively.

Bicarbonate is the predominant anion in the post-monsoon season samples, ranging from 32 to $755 \mathrm{mg} / \mathrm{L}$, except for three sample (i.e., sample No. W23, W26 and W29) in which chloride concentration was higher than that of bicarbonate. In the area of investigation, the chlorides are in the range of 11.7 to $350 \mathrm{mg} / \mathrm{L}$ during post- monsoon, and it was found that all the samples was having chloride values within the permissible limit of $1000 \mathrm{mg} / \mathrm{L}$ (BIS 1998). The sulfate content in the groundwater during the postmonsoon season varies from 32 to $170 \mathrm{mg} / \mathrm{L}$, well within the permissible limit of 400 $\mathrm{mg} / \mathrm{L}[12]$. The nitrate concentration in the region ranges from below detected limit to $31 \mathrm{mg} / \mathrm{L}$. Among the 37 samples, all sample well below the permissible limit of $45 \mathrm{mg} / \mathrm{L}$ [12].

The correlation coefficient matrix of the groundwater parameters are shown in Table 3. The moderate positive correlation coefficient $(\mathrm{r}=0.55)$ has observed between $\mathrm{Cl}^{-}$$\mathrm{NO}_{3}^{-}$referring to the anthropogenic sources of these elements (discharging of agricultural wastewater to the surface water).

Table 3. Correlation coefficient matrix of elements in water.

\begin{tabular}{|c|c|c|c|c|c|c|c|c|c|c|c|c|}
\hline & $\mathrm{pH}$ & EC & TDS & $\mathrm{TH}$ & $\mathrm{Na}$ & $\mathrm{K}$ & $\mathrm{Ca}$ & $\mathrm{Mg}$ & $\mathrm{HCO}_{3}$ & CI & $\mathrm{SO}_{4}$ & $\mathrm{NO}_{3}$ \\
\hline $\mathrm{pH}$ & 1.00 & & & & & & & & & & & \\
\hline $\mathrm{EC}$ & -0.07 & 1.00 & & & & & & & & & & \\
\hline TDS & 0.34 & 0.49 & 1.00 & & & & & & & & & \\
\hline $\mathrm{TH}$ & 0.04 & -0.14 & 0.25 & 1.00 & & & & & & & & \\
\hline $\mathrm{Na}$ & 0.19 & 0.32 & 0.58 & -0.03 & 1.00 & & & & & & & \\
\hline $\mathrm{K}$ & -0.46 & 0.12 & 0.07 & 0.09 & 0.13 & 1.00 & & & & & & \\
\hline $\mathrm{Ca}$ & -0.57 & 0.09 & -0.61 & -0.21 & -0.26 & -0.05 & 1.00 & & & & & \\
\hline $\mathrm{Mg}$ & -0.34 & 0.03 & -0.04 & 0.50 & -0.24 & -0.03 & 0.18 & 1.00 & & & & \\
\hline $\mathrm{HCO}_{3}$ & 0.14 & 0.23 & 0.38 & -0.19 & 0.45 & -0.02 & -0.19 & -0.47 & 1.00 & & & \\
\hline CI & 0.12 & 0.19 & 0.67 & 0.49 & 0.34 & 0.07 & -0.53 & 0.40 & 0.16 & 1.00 & & \\
\hline $\mathrm{SO}_{4}$ & 0.01 & 0.34 & 0.42 & -0.21 & 0.41 & -0.07 & -0.02 & -0.35 & 0.26 & 0.06 & 1.00 & \\
\hline $\mathrm{NO}_{3}$ & 0.06 & 0.21 & 0.45 & 0.45 & 0.35 & 0.27 & -0.31 & 0.09 & 0.04 & 0.55 & 0.10 & 1.00 \\
\hline
\end{tabular}




\subsubsection{Water Quality Index (WQI) Analysis}

Water quality index (WQI) method is useful for representing impairment of water quality. WQI helps for the supervision of water quality issues and improve the usefulness of shielding actions. It is an important parameter to classify water quality for suitability of drinking purposes [3]. The standards for drinking purposes as recommended by BIS (1998) have been considered for the calculation of WQI (Table 1). WQI calculation has been done by assigning weights ( $w i$ ) according to relative importance of each chemical parameter for drinking purposes (Table 4). The parameters like total dissolved solids, chloride sulfate and nitrate has been assigned highest weight 5 because of the chief significance in water quality valuation [13]. Other parameters like calcium, magnesium, sodium, total hardness (TH), manganese and potassium were gave weight between 1 and 5 depending on their prominence in water quality purpose. The relative weight ( $W i$ ) is computed (Table 4 ) from the following Equation:

$$
W i=\frac{W i}{\sum_{i=1}^{N} W i}
$$

where, $W i$ is the relative weight, wi is the weight of each parameter and $n$ is the number of parameters.

A quality rating scale $\left(q_{i}\right)$ for each parameter is assigned by dividing its concentration in each water sample by its respective standard according to the guidelines laid down in the $[14]$ and the result is multiplied by 100 :

$$
q_{i}=\left(C_{i} / S_{i}\right) \times 100
$$

where, $q_{i}$ is the quality rating, $C_{i}$ is the concentration of each chemical parameter in each water sample in milligrams per liter, $S_{i}$ is the Indian drinking water standard for each chemical parameter in milligrams per liter according to the guidelines of the [12]. For computing the WQI, the SI is first determined for each chemical parameter, which is then used to determine the WQI as per the following equation:

Table 4. Relative weight of chemical parameters.

\begin{tabular}{ccc}
\hline Chemical parameters & Weight $(w 1)$ & Relative weight \\
\hline $\mathrm{TDS}$ & 5 & 0.135 \\
$\mathrm{pH}$ & 4 & 0.108 \\
$\mathrm{HCO}_{3}$ & 1 & 0.027 \\
$\mathrm{CI}$ & 5 & 0.135 \\
$\mathrm{SO}_{4}$ & 5 & 0.135 \\
$\mathrm{NO}_{3}$ & 5 & 0.135 \\
$\mathrm{Ca}$ & 3 & 0.081 \\
$\mathrm{Mg}$ & 3 & 0.081 \\
$\mathrm{Na}$ & 4 & 0.108 \\
$\mathrm{~K}$ & 2 & 0.054 \\
& 37 & 1.000 \\
\hline
\end{tabular}




$$
\begin{aligned}
& S I i=W i \times q i \\
& W Q I=\sum S I i
\end{aligned}
$$

where, SIi is the sub-index of ith parameter, $q i$ is the rating based on concentration of ith parameter, $n$ is the number of parameters. The WQI range and type of water can be classified as excellent water $(<50)$; good water $(50-100)$; poor water $(100-200)$; very poor water (200 - 300); water unsuitable for drinking purposes $(>300)$ (Table 3). The calculated WQIvalues of the study area range from 88.0 to 307.61 .

Out of 37 groundwater sample, $5.41 \%$ in represents good water, $62.16 \%$ indicate poor water, and $29.73 \%$ shows very poor water and $2.7 \%$ indicate water unsuitable for drinking purposes. This may be due to effective leaching of ions, overexploitation of groundwater, direct discharge of effluents, and agricultural impact [3]. The high value of WQI at some locations has been found to be mainly from the higher values of nitrate, total dissolved solids, hardness, bicarbonate and manganese in the ground- water.

\subsection{Groundwater Quality Analysis for Irrigation}

The irrigation practice is mainly dependent upon water quality, type of soil and type of crop. The productivity of irrigation has been hampered by high amounts of soluble ions in irrigation water; this water affects crop and soil fertility. The biochemical effects disturb crop metabolism. The important chemical constituents that affect the suitability of water for irrigation, which can be utilized to verify the suitability, are as follows

\subsubsection{Salinity Index}

Based on the analysis, the groundwater samples have been classified [14] and are given in Table 5. It is found that all the samples collected during the post-monsoon season of the year 2014 are categorized under high to high extensive salinity classes. The Groundwater quality index value for irrigation is given in Table 6 . The majority of the samples $(62.16 \%)$ belong to the high salinity category, representative that the water is of permissible quality. Those high salinity (class 3 ) exhibiting value are suitable for irrigating

\begin{tabular}{|c|c|c|c|}
\hline $\mathrm{EC}(\mu \mathrm{S} / \mathrm{cm})$ & Water salinity & Range (no. of samples) & Percent \\
\hline $0-250$ & Low & -- & -- \\
\hline $251-750$ & Medium & -- & -- \\
\hline $751-2250$ & High & 860 - 2246 (13 sample) & 35.14 \\
\hline $2251-6000$ & Very high & 2738 - 5290 (23 sample) & 62.16 \\
\hline $6001-10,000$ & Extensively high & 6770 (1 sample) & 2.70 \\
\hline $10,001-20,000$ & Brines weak concentration & -- & -- \\
\hline $20,001-50,000$ & Brines moderate concentration & -- & -- \\
\hline $50,001-100,000$ & Brines high concentration & -- & -- \\
\hline$>100,000$ & Brines extremely high concentration & -- & -- \\
\hline
\end{tabular}

Table 5. Classification of waters based on of EC [3]. 
Table 6. Groundwater quality index value for irrigation for post-monsoon 2014.

\begin{tabular}{|c|c|c|c|c|c|c|c|}
\hline Location & SAR & $\% \mathrm{Na}$ & SSP & RSC & PI & KI & $\mathrm{MH}$ \\
\hline W1 & 1.028 & 18.599 & 18.371 & -1.89 & 41.238 & 0.225 & 22.090 \\
\hline W2 & 0.909 & 19.816 & 19.602 & -0.004 & 50.080 & 0.244 & 53.255 \\
\hline W3 & 0.499 & 9.475 & 9.281 & -5.99 & 27.800 & 0.102 & 32.506 \\
\hline W4 & 0.645 & 9.504 & 9.242 & -15.59 & 18.809 & 0.102 & 29.529 \\
\hline W5 & 0.483 & 7.286 & 7.130 & -14.73 & 17.693 & 0.077 & 28.237 \\
\hline W6 & 0.720 & 11.389 & 11.052 & -13.82 & 20.174 & 0.124 & 24.991 \\
\hline W7 & 0.573 & 9.117 & 8.814 & -14.32 & 18.132 & 0.097 & 30.497 \\
\hline W8 & 0.676 & 11.353 & 11.131 & -11.92 & 21.065 & 0.125 & 16.372 \\
\hline W9 & 1.047 & 15.811 & 15.651 & -6.06 & 32.281 & 0.186 & 22.211 \\
\hline W10 & 0.787 & 10.133 & 10.009 & -17.67 & 19.757 & 0.111 & 22.041 \\
\hline W11 & 1.455 & 18.229 & 18.126 & -14.53 & 28.200 & 0.221 & 15.621 \\
\hline W12 & 1.096 & 13.947 & 13.833 & -16.76 & 23.282 & 0.161 & 18.375 \\
\hline W13 & 1.01 & 13.145 & 13.00 & -18.58 & 20.93 & 0.14 & 30.08 \\
\hline W14 & 0.90 & 17.55 & 17.42 & -4.89 & 36.06 & 0.21 & 54.15 \\
\hline W15 & 0.69 & 13.80 & 13.68 & -5.74 & 31.34 & 0.15 & 58.31 \\
\hline W16 & 1.07 & 24.20 & 24.02 & -2.10 & 49.23 & 0.31 & 58.43 \\
\hline W17 & 1.19 & 23.86 & 23.76 & -2.27 & 47.08 & 0.31 & 44.53 \\
\hline W18 & 6.53 & 65.52 & 65.39 & 2.08 & 81.81 & 1.88 & 67.40 \\
\hline W19 & 4.99 & 57.86 & 57.77 & 2.34 & 76.77 & 1.36 & 33.30 \\
\hline W20 & 9.33 & 75.16 & 75.12 & 7.59 & 93.42 & 3.01 & 60.25 \\
\hline W21 & 9.89 & 80.14 & 80.09 & 6.53 & 100.4 & 4.02 & 65.29 \\
\hline W22 & 1.13 & 22.01 & 21.52 & -2.95 & 43.22 & 0.27 & 67.29 \\
\hline W23 & 2.00 & 29.91 & 29.60 & -7.42 & 41.90 & 0.42 & 66.58 \\
\hline W24 & 8.80 & 78.89 & 78.78 & 7.41 & 102.92 & 3.71 & 64.42 \\
\hline W25 & 2.40 & 37.97 & 37.59 & -0.725 & 58.709 & 0.60 & 62.20 \\
\hline W26 & 1.81 & 32.55 & 32.15 & -6.814 & 38.853 & 0.47 & 67.29 \\
\hline W27 & 2.94 & 41.26 & 41.17 & -4.23 & 55.466 & 0.70 & 72.78 \\
\hline W28 & 2.06 & 38.98 & 38.70 & -1.568 & 60.957 & 0.63 & 67.42 \\
\hline W29 & 1.21 & 17.83 & 17.76 & -10.52 & 29.75 & 0.21 & 67.29 \\
\hline W30 & 2.60 & 39.10 & 38.67 & -1.256 & 58.043 & 0.63 & 46.20 \\
\hline W31 & 5.17 & 60.08 & 60.02 & 1.998 & 78.99 & 1.50 & 63.78 \\
\hline W32 & 2.47 & 37.44 & 37.27 & -2.583 & 55.149 & 0.59 & 62.92 \\
\hline W33 & 1.13 & 14.52 & 14.41 & -17.80 & 22.76 & 0.16 & 15.58 \\
\hline W34 & 0.86 & 9.954 & 9.853 & -24.17 & 17.459 & 0.10 & 18.30 \\
\hline W35 & 5.02 & 43.83 & 43.76 & -18.85 & 47.56 & 0.77 & 28.44 \\
\hline W36 & 1.02 & 16.42 & 16.13 & -11.55 & 25.786 & 0.19 & 31.20 \\
\hline W37 & 0.77 & 10.54 & 10.41 & -20.44 & 15.567 & 0.11 & 34.33 \\
\hline
\end{tabular}


the medium and high salt-tolerant crops. High salinity water (class 4) is suitable for watering the high salt-tolerant crops, while water of salinity class 5 or above is usually unsuitable for irrigation.

\subsubsection{SAR or Sodicity Index}

High sodium-depositing waters are largely not appropriate for watering the soils, as developed deposition of sodium may worsen the soil physical characteristics. Therefore, SAR is reflected a superior quantity of sodium threat in irrigation, as SAR of water is directly connected to the adsorption of sodium by topsoil and is a valued measure for decisive the appropriateness of the water for irrigation. The SAR is used to predict the sodium hazard of high carbonate waters, particularly if they contain no residual alkali. The SAR which is computed as below.

$$
\mathrm{SAR}=\frac{\mathrm{Na}^{+}}{\left\{\frac{\mathrm{Ca}^{2+}+\mathrm{Mg}^{2+}}{2}\right\}^{0.5}}
$$

where all cationic concentrations are expressed in equivalents per million or mill equivalents per litre.

The grouping of groundwater samples from the study area with respect to SAR [15] is represented in Table 7. During post-monsoon, the SAR value of all the samples are found to be less than 10 and are classified as excellent for irrigation (i.e. S1 category).

\subsection{3. \% Na}

The Wilcox (1995) and Richards (1954) have been used to categorize and recognize the elementary properties of the chemical composition of groundwater, since the mineral properties of water that effects plants and soil are measured by the suitability groundwater for irrigation. Percent sodium can be determined using the following formula:

$$
\% \mathrm{Na}=\left(\frac{\mathrm{Na}^{+}+\mathrm{K}^{+}}{\left(\mathrm{Ca}^{2+}+\mathrm{Mg}^{2+}+\mathrm{Na}^{+}+\mathrm{K}^{+}\right)}\right) * 100
$$

where the quantities of $\mathrm{Ca}^{2+}, \mathrm{Mg}^{2+}, \mathrm{Na}^{+}$and $\mathrm{K}^{+}$are expressed in milliequivalents per liter or equivalents per million. The classification of groundwater samples with respect to percent sodium is shown in Table 8 and it was found that 20 samples (54.05\%) belong to the excellent to good category, 9 samples in good water class, 3 samples in permissible water class, 4 samples in doubtful water class and 1 sample unsuitable water class.

Table 7. Classification of waters based on SAR values [15] [16] and sodium hazard classes based on USSL classification.

\begin{tabular}{cccc}
\hline SAR values & Sodium hazard class & Remark & Sample \\
\hline$<10$ & S1 & Excellent & 0.5 to 9.90 all sample \\
$10-18$ & S2 & Good & \\
$19-26$ & S3 & Doubtful/fair poor & \\
$>26$ & S4 and S5 & Unsuitable & \\
\hline
\end{tabular}


Table 8. Sodium percent water class [17].

\begin{tabular}{ccc}
\hline Sodium $(\%)$ & Water class & Range (\% samples) \\
\hline$<20$ & Excellent & $7.29-19.82(54.05 \%$ sample $)$ \\
$20-40$ & Good & $22.02-39.11(24.32 \%$ sample $)$ \\
$40-60$ & Permissible & $41.27-57.87(8.11 \%$ sample $)$ \\
$60-80$ & Doubtful & $60.09-78.90(10.82 \%$ sample $)$ \\
$>80$ & Unsuitable & $2.70 \%$ sample $)$ \\
\hline
\end{tabular}

\subsubsection{Soluble Sodium Percentage (SSP)}

Groundwater quality for agricultural purposes in the Ghod river basin shows variation between excellent and good based on Todd's classification of SSP values, which is calculated as:

$$
\mathrm{SSP}=\left(\frac{\mathrm{Na}^{+}}{\left(\mathrm{Ca}^{2+}+\mathrm{Mg}^{2+}+\mathrm{Na}^{+}\right)}\right) * 100
$$

where all concentrations are in milliequivalents per liter. The SSP values ranged from 7.13 to 80.09 for the post-monsoon season of the year 2014 (Table 6). Out of 37 samples, 6 samples unsuitable for irrigation, 31 samples suitable for irrigation.

\subsubsection{Residual Sodium Carbonate (RSC)}

In addition to the SAR and $\% \mathrm{Na}$, the additional carbonate in groundwater over the sum of calcium and magnesium also influences the suitability of groundwater for irrigation. The high concentration sodium bicarbonate and carbonate is measured the damaging physical properties of soils, as there is tendency for calcium and magnesium to precipitate as the water in the soil. The relative proportion of sodium in the water is increased in the form of sodium carbonate, and this excess, denoted by RSC, is calculated as follows

$$
\mathrm{RSC}=\left(\mathrm{CO}_{3}+\mathrm{HCO}_{3}\right)-(\mathrm{Ca}+\mathrm{Mg})
$$

In addition where all ionic concentrations are expressed in equivalents per million or milliequivalents per liter. The groundwater in the study area is classified on the basis of RSC after Richards 1954 and the results are presented in Table 9 for the post-monsoon seasons. Based on the RSC values, $8.11 \%$ samples showed RSC values more than 2.50 epm, reflected to unsuitable for irrigation. The negative RSC values in 31 samples indicated that dissolve $\mathrm{Ca}^{2+}$ and $\mathrm{Mg}^{2+}$ ion contents was more than the $\mathrm{CO}_{3}^{2-}$ and $\mathrm{HCO}_{3}^{-}$ contents. The remaining 31 samples (83.78\%) were having a RSC value below $1.25 \mathrm{epm}$, and only four samples $(8.11 \%)$ belong to the doubtful category.

\subsubsection{Permeability Index (PI)}

The PI values also indicate suitability of groundwater for irrigation, as the soil permeability is affected by long-term use of irrigation water, influenced by the $\mathrm{Na}^{+}, \mathrm{Ca}^{2+}, \mathrm{Mg}^{2+}$, and $\mathrm{HCO}_{3}^{-}$contents of the soil. Ragunath (1987) [7] and Doneen (1964) [8] evolved a 
standard for measuring the suitability of water for irrigation based on PI, and waters can be classified as classes 1, 2, and 3. The PI can be written as follows:

$$
\mathrm{PI}=\frac{\mathrm{Na}^{+}+\sqrt{\mathrm{HCO}_{3}^{-}}}{\left(\mathrm{Ca}^{2+}+\mathrm{Mg}^{2+}+\mathrm{Na}^{+}\right)} * 100
$$

where the concentrations are reported in milliequivalents per liter.

The permeability index of the Dimbhe command area ranges from $15.56 \%$ to $93.42 \%$ during the post-monsoon in November 2014 (Table 10). According to the permeability index values, $54.05 \%$ of the samples fall under class 2 (PI ranged from $25 \%$ to $75 \%$ ) and $29.73 \%$ samples belong to class unsuitable (PI < 25\%) in the post-monsoon in November 2014.

\subsubsection{Kelly's Index (KI)}

Sodium measured against $\mathrm{Ca}^{2+}$ and $\mathrm{Mg}^{2+}$ is used to calculate Kelley's ratio [20] [21]. A Kelly's index of more than 1 shows an extra concentration of sodium in waters (Table 11). Hence, groundwater's with a Kelly's index less than 1 are suitable for irrigation, while those with a ratio more than 1 are unsuitable. Kelly's index in the present study varied from 0.11 to 3.71. The sample number W18, W19, W20, W21, W24 and W31 are unsuitable for irrigation based on Kelly index.

\subsubsection{Magnesium Hazard ( $\mathrm{MH}$ )}

The Calcium and magnesium do not behave equally in the soil system, and magnesium deteriorates soil structure particularly when waters are sodium dominated and highly saline. A high level of $\mathrm{Mg}$ is usually due to the presence of exchangeable $\mathrm{Na}$ in irrigated

Table 9. Groundwater quality based on RSC [18].

\begin{tabular}{ccc}
\hline RSC (epm) & Remark on quality & Range (\% samples) \\
\hline$<1.25$ & Good & $-24.17-0.004(83.78 \%)$ \\
$1.25-2.50$ & Doubtful & $1.99-2.34(8.11 \%)$ \\
$>2.50$ & Unsuitable & $6.53-7.59(8.11 \%)$ \\
\hline
\end{tabular}

Table 10. Classification of irrigation water based on the permeability index [19].

\begin{tabular}{cccc}
\hline \multirow{2}{*}{ Groundwater samples } & \multicolumn{3}{c}{ PI } \\
\cline { 2 - 4 } & $>75 \%$ & $25 \%-75 \%$ & $<25 \%$ \\
\cline { 2 - 4 } & Excellent & Good & Unsuitable \\
\hline Post monsoon & 6 & 20 & 11 \\
\hline
\end{tabular}

Table 11. Kelley's ratio [20] [21].

\begin{tabular}{ccc}
\hline \multirow{2}{*}{ Groundwater samples } & \multicolumn{2}{c}{ K.I. } \\
\cline { 2 - 3 } & Suitable & $>1$ \\
\cline { 2 - 3 } & 31 & Unsuitable \\
\hline Post Monsoon Nov. 2014 & & 6 \\
\hline
\end{tabular}


soils. Paliwal (1972) [22] introduced an important ratio called index of magnesium hazard. Magnesium hazard value of more than $50 \%$ would adversely affect the crop yield as the soils become more alkaline:

$$
\mathrm{MH}=\frac{\mathrm{Mg}^{2+}}{\left(\mathrm{Ca}^{2+} \times \mathrm{Mg}^{2+}\right) \times 100}
$$

The $\mathrm{MH}$ values are reported to be in the range of $15.58 \%$ to $72.78 \%$. Out the 37 samples, $23.4 \%$ of the samples showed a magnesium ratio below $50 \%$, suggesting their suitability, while only $76.6 \%$ fall in the unsuitable category with $\mathrm{MH}$ more than $50 \%$, indicating their adverse effect on crop yield (Table 12).

\subsubsection{Boron}

The groundwater samples containing boron is in the range of below detection limit to $8.01 \mathrm{mg} / \mathrm{L}$. The proposed limits of boron concentration in irrigation water and the total number of groundwater samples of the study area representing the boron classes (McCarthy and Ellery 1994) are presented in (Table 13). In semi sensitive crop type 14 samples are unsuitable and Semi-tolerant and tolerant crops 10 samples are unsuitable.

\section{Discussion}

The groundwater sources in the Ghod River basin, Pune District, were evaluated for their chemical configuration and suitability for irrigation uses. Physico-chemical analyses of groundwater revealed that there are substantial changes observed in the $\mathrm{pH}$ and EC during pre-monsoonal period. The subsurface aquifer system buffers the alkaline $\mathrm{pH}$ towards neutral at near dam site. However, lower reaches get accumulated show gradual increase in the $\mathrm{pH}$ values. Further, variation EC values indicate highly saline water in the middle part of study area.

Table 12. Irrigation water quality classification based on Magnesium Hazards [22].

\begin{tabular}{ccc}
\hline \multirow{2}{*}{ Groundwater samples } & \multicolumn{2}{c}{ MH } \\
\cline { 2 - 3 } & Safe and Suitable & $>50$ \\
\cline { 2 - 3 } & 20 & Unsuitable \\
\hline Post Monsoon Nov. 2014 & & 17 \\
\hline
\end{tabular}

Table 13. Irrigation water quality classification based on boron concentration.

\begin{tabular}{ccccc}
\hline \multirow{2}{*}{ Boron class } & \multicolumn{2}{c}{ Semi-sensitive crops } & \multicolumn{2}{c}{ Semi-tolerant and tolerant crops } \\
\hline \multirow{2}{*}{ Excellent } & Range $(\mathrm{mg} / \mathrm{L})$ & No of sample & Range $(\mathrm{mg} / \mathrm{L})$ & No of sample \\
Good & $<0.33$ & 7 samples & $<0.67$ & 13 samples \\
Permissible & $0.33-0.67$ & 6 samples & $0.67-1.33$ & 10 samples \\
Doubtful & $0.67-1$ & 6 samples & $1.33-2.0$ & 3 samples \\
Unsuitable & $1-1.125$ & 6 samples & $2.0-2.5$ & 1 samples \\
\hline
\end{tabular}


In cations, $\mathrm{Ca}$ and $\mathrm{Mg}$ show exceeding high concentration post monsoon, chemical weathering of primary silicates in the basaltic lithology imparts the calcium ions while due to prevalent semi-arid conditions, evaporation dominance results into calcrete deposition as well as calcium in groundwater. The majority of samples $\mathrm{Ca}^{2+}$ and $\mathrm{Mg}^{2+}$ have originated not only from carbonate minerals, but also from other sources. In these samples even after forming aqueous species, such as $\mathrm{Ca}^{2+}-\mathrm{HCO}_{3}^{-}$and $\mathrm{Mg}-\mathrm{HCO}_{3}^{-}$, there is surplus $\mathrm{Ca}^{2+}$ and $\mathrm{Mg}^{2+}$ which could have affinity for the relatively abundant $\mathrm{SO}_{4}^{2-}$ ions. Therefore, ionic aqueous species such as $\mathrm{Mg}-\mathrm{SO}_{4}^{2-}$ and $\mathrm{Ca}^{2+}-\mathrm{SO}_{4}^{2-}$ may be expected in almost all samples in post monsoon.

Major anions like $\mathrm{HCO}_{3}$ are the weathering product of primary silicates like olivine, plagioclase and pyroxene and $\mathrm{SO}_{4}$ is from anthropogenic source while, $\mathrm{Cl}$ enters through subsurface aqueous system as the result of groundwater salinization. However, $\mathrm{NO}_{3}$ enters in groundwater system as partial fractions of anthropogenic inputs (nitrogenous fertilizers) from agricultural activity.

The suitability of groundwater for irrigation was evaluated based on the irrigation quality parameters like boron, SAR, \%Na, RSC, SSP, permeability index, Kelley's ratio, and magnesium hazard. Among these parameters, SAR, boron, KI, MH, MR, and \% Na imply that the water samples fall in excellent, suitable, unsuitable, safe to unsafe, and excellent to permissible, respectively, for irrigation. RSC values specify that water samples belong to good to unsuitable classes. Permeability index recommends that the water samples from the Dimbhe command area, belonging to classes 1 and 2, are suitable for irrigation. Water that is not suitable based on the above classification may be suitable in well-drained soils.

\section{Conclusions}

Groundwater quality and its suitability for domestic and agricultural uses in the Dimbhe command area of River Ghod, Maharashtra, India were evaluated since it is a major source of water for domestic and agricultural activities in the study area.

The statistical analyses were used for determining the groundwater quality variations. A correlation analysis between two hydrochemical parameters groups of species is showing moderate correlation. The cause of this situation is suggested that the simultaneous increase/decrease in the parameter ( $\mathrm{pH}, \mathrm{TDS}, \mathrm{Ca}, \mathrm{Na}, \mathrm{Cl}$ and $\mathrm{NO}_{3}$ ) is the consequence chiefly of dissolution/precipitation reaction and concentration effects.

Water Quality Index was used to determine the groundwater quality and its suitability for drinking purposes. According to the WQI, 5.41\% of groundwater samples represent "Goodwater", 62.16\% indicate "poor water", and $29.73 \%$ show "very poor water" and $2.7 \%$ "unsuitable water". This situation was thought to be due to effective leaching of ions, overexploitation of groundwater, direct discharge of effluents, and agricultural impact.

The various indices derived in the study indicate that the most of groundwater of the study area is suitable for agriculture irrigation use. The long-term use of such groundwater for irrigation will induce sodium hazard to soils. It will have negative impacts on 
the yields of crops and properties of soils. However, mixing of low and high salinity water is recommended before irrigation to reduce the salinity hazard in local areas.

Finally, based on these studies, recommendations have been made to the local authorities to adopt conjunctive use of surface water with groundwater to stringently monitor and control low groundwater quality regions to ensure sustainable safe use of the resource.

\section{References}

[1] Choudhary, S., Ramteke, S., Rajhans, K.P., Sahu, P.K., Chakradhari, S., Patel, K.S. and Matini, L. (2016) Assessment of Groundwater Quality in Central India. Journal of Water Resource and Protection, 8, 12-19. https://doi.org/10.4236/jwarp.2016.81002

[2] Nagaraju, A., Muralidhar, P. and Sreedhar, Y. (2016) Hydrogeochemistry and Groundwater Quality Assessment of Rapur Area, Andhra Pradesh, South India. Journal of Geoscience and Environment Protection, 4, 88-99. ttps://doi.org/10.4236/gep.2016.44012

[3] Singh, S., Raju, N.J. and Ramakrishna, Ch. (2015) Evaluation of Groundwater Quality and Its Suitability for Domestic and Irrigation Use in Parts of the Chandauli-Varanasi Region, Uttar Pradesh, India. Journal of Water Resource and Protection, 7, 572-587. https://doi.org/10.4236/jwarp.2015.77046

[4] Hounslow, A.W. (1995) Water Quality Data: Analysis and Interpretation. CRC Press LLC, Lewis Publishers, Boca Raton.

[5] Fetter Jr., C.W. (2000) Applied Hydrogeology. 4th Edition, Prentice-Hall, Upper Saddle River, 598 p.

[6] Hem, J.D. (1989) Study and Interpretation of Chemical Characteristics of Natural Waters. 3rd Edition, US Geological Survey Water Supply Paper 2254.

[7] Selvakumar, S., Ramkumar, K., Chandrasekar, N., Magesh, N.S. and Kaliraj, S. (2014) Groundwater Quality and Its Suitability for Drinking and Irrigational Use in the Southern Tiruchirappalli District, Tamil Nadu, India. Applied Water Science, 1-10. https://doi.org/10.1007/s13201-014-0256-9

[8] Khurshid, S.H., Hasan, N. and Zaheeruddin (2002) Water Quality Status and Environmental Hazards in Parts of Yamuna-Karwan Sub-Basin of Aligarh-Mathura District, Uttar Pradesh, India. Journal of Applied Hydrology, 15, 30-37.

[9] Jafar Ahmed, A., Loganathan, K. and Ananthakrishnan, S. (2013) A Comparative Evaluation of Groundwater Suitability for Drinking and Irrigation Purposes in Pugalur Area, Karur District, Tamilnadu, India. Scholar Research Library, 5, 213-223.

[10] Raju, N.J., Shukla, U.K. and Ram, P. (2011) Hydrogeochemistry for the Assessment of Groundwater Quality in Varanasi: A Fast-Urbanizing Center in Uttar Pradesh, India. Environmental Monitoring and Assessment, 173, 279-300. https://doi.org/10.1007/s10661-010-1387-6

[11] American Public Health Association (APHA) (2005) Standard Method for Examination of Water and Wastewater. 21st Edition, APHA, AWWA, WPCF, Washington.

[12] BIS (1998) Drinking Water Specifications (Revised 2003). IS:10500, Bureau of Indian Standards, New Delhi.

[13] Srinivasamoorthy, K., Chidambaram, M., Prasanna, M.V., Vasanthavigar, M., Peter, J. and Anandhan, P. (2008) Identification of Major Sources Controlling Groundwater Chemistry from a Hard Rock Terrain-A Case Study from Mettur Taluk, Salem District, Tamil Nadu, India. Journal of Earth System Sciences, 117, 49-58. 
[14] Eaton, E.M. (1950) Significance of Carbonate in Irrigation Water. Soil Science, 69, 12-133. https://doi.org/10.1097/00010694-195002000-00004

[15] Todd, D.K. (1959) Groundwater Hydrology. Wiley, New York, 535.

[16] Richards, L.A. (US Salinity Laboratory) (1954) Diagnosis and Improvement of Saline and Alkaline Soils. Hand Book No. 60, US Department of Agriculture, Washington DC.

[17] Wilcox, L.V. (1995) Classification and Use of Irrigation Waters. US Department of Agriculture, Washington DC, 19.

[18] Raghunath H.M. (1987) Groundwater. New Age International (P) Ltd., New Delhi.

[19] Doneen, L.D. (1964) Notes on Water Quality in Agriculture. Water Science and Engineering, University of California, Davis.

[20] Kelley, W.P. (1940) Permissible Composition and Concentration of Irrigation Waters. Proceedings of ASCE, 66, 607-614.

[21] Kelley, W.P. (1951) Alkali Soils-Their Formation, Proper-Ties and Reclamation. Reinhold, New York.

[22] Paliwal, K.V. (1972) Irrigation with Saline Water. Monogram No. 2, New Series, IARI, New Delhi, 198.

\section{Submit or recommend next manuscript to SCIRP and we will provide best service} for you:

Accepting pre-submission inquiries through Email, Facebook, LinkedIn, Twitter, etc. A wide selection of journals (inclusive of 9 subjects, more than 200 journals)

Providing 24-hour high-quality service

User-friendly online submission system

Fair and swift peer-review system

Efficient typesetting and proofreading procedure

Display of the result of downloads and visits, as well as the number of cited articles

Maximum dissemination of your research work

Submit your manuscript at: http://papersubmission.scirp.org/

Or contact gep@scirp.org 